\title{
Resistance of Two Maize Landraces in Breeding Stage to the Attack of Sitophilus zeamais
}

\author{
Rejane Teixeira do Nascimento', Bruno Ettore Pavan², Luciana Barboza Silva', \\ Gabriel dos Santos Carvalho ${ }^{1}$, Alexandre Faria da Silva ${ }^{1}$, Kellen Maggioni ${ }^{1}$ \\ ${ }^{1}$ Graduate Program in Agronomy-Crop Science, Federal University of Piauí, Bom Jesus, Brazil \\ ${ }^{2}$ College of Engineering of Ilha Solteira-DFTASE-UNESP, São Paulo, Brasil \\ Email: rejane.teixeira09@hotmail.com
}

Received 3 July 2014; revised 15 August 2014; accepted 28 August 2014

Copyright (C) 2014 by authors and Scientific Research Publishing Inc.

This work is licensed under the Creative Commons Attribution International License (CC BY). http://creativecommons.org/licenses/by/4.0/

\section{(c) (i) Open Access}

\begin{abstract}
This study aimed to assess the resistance of grain from two varieties of maize landraces in initial breeding in Bom Jesus-PI, with respect to $S$. zeamais attack. Seeds of two maize landraces were used: purple straw maize from two different origins (São Paulo (SP) and Espírito Santo (ES)) and Peruvian purple maize. The experimental design was completely randomized with four replications. The data for each response variable were subjected to analysis of variance, applying the F-test ( $p \leq$ 0.05), and when significant differences were found, there was a comparison of means by Tukey test $(p \leq 0.05)$. The statistical analyses were performed using the software ${ }^{\circledR}{ }^{\circledR}{ }^{\circledR}$. In a free-choice test and bioassay for evaluating the nutritional index (no choice test), maize varieties differed significantly by Tukey test and the cultivar SP was considered resistant, while the cultivars purple and ES were considered susceptible.
\end{abstract}

\section{Keywords}

Selection, Genetic Variability, Susceptibility

\section{Introduction}

In recent decades there have been significant advances in understanding the composition of cereals, corn having been studied extensively. A direct consequence of this study was genetic improvement optimizing its many uses, both for the food industry and for high-tech industries. Thus, the physical and chemical quality of the grain and the industrial processes used to produce various products have large influence, resulting in the concept of corn 
as a raw material of high value [1]. Brazil is the third largest producer of corn, with an average contribution of $6 \%$ of the world supply [2]. The crop is planted throughout the Brazilian territory, set apart from others by occupying the largest planted area in the country [3].

Genetic improvement of corn has contributed significantly to the increase in productivity in Brazil, and the search for additional gains by selection has been complemented by efforts to improve other important agronomic traits that, directly or indirectly, have influence on crop yield [4].

The contribution of genetic improvement in increasing crop productivity is, without doubt, one of the most significant since the development and use of hybrid corn yielded, in a short time, an increase in productivity of more than $150 \%$ [5]. From the early twentieth century, various breeding programs were initiated using scientific bases. The development of pure lines, derived from the process of self-pollination of corn plants for several generations, and from hybrid vigor, or heterosis, was responsible for the boost that conventional breeding achieved in the early last century [6].

This knowledge allowed breeding programs to introduce new features to corn, such as resistance to diseases and pests, greater protection of grain through better casing, increased response to management practices, better nutritional quality and less tipping and breaking of plants [5]. In this context, the use of improved varieties, well adapted and with desirable agronomic attributes, in place of traditional varieties, will provide improvements in corn yields [7].

Sitophilus zeamais (Motschulsky) (Coleoptera: Curculionidade), popularly known as the maize weevil, is considered one of the most important storage pests in tropical regions [8]. Thus, resistant varieties can be an alternative to control this pest due to ease of use, not burdening the product, absence of contamination in grain, compatibility with other control methods, and offering less risk to human and animal health [9]. To develop varieties resistant to insect pests studies are needed to detect genotypes to serve as a source of resistance.

Potrich et al. [10] found that the hardness and the color of the grain do not interfere with the feeding preference of insect. For Morais and Pinheiro in Fritsche-Neto and Borém [11], the size of the infesting population influences the manifestation of resistance. In addition, several other factors may influence the resistance of corn grain to S. zeamais. Sing and McCain [12] and Veiga [13] found that chemical composition and especially lowsugar content are important factors for resistance.

This study aimed to evaluate the resistance of grains of maize landrace varieties in breeding phase in Bom Jesus-PI, with respect to the attack S. zeamais, during storage of the grain.

\section{Materials and Methods}

The experiments were performed at the Federal University of Piauí (UFPI/CPCE) in the town of Bom Jesus, PI, in the period of 2011/2013, using seed of two landrace varieties of maize, Peruvian purple maize (Purple) and purple straw maize (origins from São Paulo (SP) and Espírito Santo (ES)), in early breeding, being conducted by this university. The landraces have high genetic diversity, are constantly evolving process and adaptation to environmental conditions and cropping systems [14]. During cultivation was carried fertilization at planting and hedging in accordance with the technical recommendations for the planting area, based on chemical analysis of soils in the region. Supplemental irrigation was performed using sprinklers to ensure the production of crops in times of drought. Was held, when necessary, hand weeding, aiming to weed control in the experiment. The seeds received no treatment for the control of insect pests or fungi. The adults of $S$. zeamais used in this experiment were obtained from the laboratory stock population.

The free choice test was performed using an arena consisting of a circular plastic tray of $15 \mathrm{~cm} \times 8 \mathrm{~cm}$, filled with Styrofoam with a height of $7 \mathrm{~cm}$. The same was provided with five cylindrical holes in the extremities, with transparent plastic vials $5 \mathrm{~cm} \times 7 \mathrm{~cm}$, equidistant from a central circle of $5 \mathrm{~cm}$ in diameter containing a cover with an orifice of $10 \mathrm{~cm}$ radius in the middle, closed with white "voile" tissue. The central region received 50 adult insects, not sexed; the vials received fifty grams of grains of the two maize landrace varieties (3 sources). The experiment was conducted with five replicates and assessment of the number of insects on each maize variety occurred $0.5 \mathrm{~h}, 1 \mathrm{~h}, 12 \mathrm{~h}, 24 \mathrm{~h}, 48 \mathrm{~h}$ and $72 \mathrm{~h}$ after exposure.

The bioassay for assessing the nutritional index was completely randomized in design with ten replicates (no choice test). The experiment consisted of plastic jars (150 ml), containing $10 \mathrm{~g}$ of maize grain and infested with 30 unsexed adult insects of $S$. zeamais. After 10 days, the insects were removed, the number of live and dead insects was counted and they subsequently were weighed. After removal of insects the final grain weight was 
measured on an analytical balance. The following nutritional indexes were calculated for each combination of deltamethrin-sprayed dose and maize weevil strain, as described elsewhere [15] [16]: relative growth rate (RGR) (daily weight gain per unit of insect weight), relative consumption rate (RCR) (daily consumption rate per unit of insect weight), conversion efficiency of ingested food (ECI) (relative growth rate/relative consumption rate)\%. Thereafter, the same material was used to determine the rate of population growth. After 90 days, the emergence (EMERG) and number of dead insects (NDI) was recorded.

The data for each response variable were subjected to analysis of variance, applying the F-test $(p \leq 0.05)$ and, when significant differences were observed, a comparison of means was done by Tukey test $(p \leq 0.05)$. The statistical analyses were performed using SAS. The heritability was estimated using the formula described by [17].

\section{Results and Discussion}

Santos \& Foster [18] reported that the maize weevil is able to distinguish resistant grain from susceptible grain, even when mixed, in a "free choice" test. According to them, this insect can be used as an agent of selection for resistance in a maize population where there is genetic variability. In Table 1 it was found that there was an attractive effect of all materials tested, but significant differences were observed in the percentage of insects found in each material in accordance with the particular observation time. The precision estimated by the coefficient of variation (CV) was high, ranging from $27 \%$ to $76 \%$, as were the values of heritability.

It is noted (Table 1) that in the first hours there was a similar distribution among the arenas. There is movement to recognize feeding and oviposition sites. The insects were attracted, remained for a period of time and then sought more suitable feeding and oviposition sites. According to [19], there is larval competition within the grains, so the large number of insects present in the container leads the insects to seek more appropriate sites, which according to the results, are not related to the attractiveness, as the movement of insects between varieties was not significant.

Also according to this table, the number of insects present in purple corn straw origins Sao Paulo, stood out in time at 24 hours, being significantly higher (14.0) than those found in other materials, making it the most attractive under the conditions of the experiment. There are intrinsic factors of maize that attracted insects at this period. Probably, there are resistance factors (chemical or physical characteristics of the grain) acting to inhibit or attract insects in some of the materials [20], therefore aiming to reduce the attack of insects. The plants develop various defense mechanisms which include physical and chemical barriers, and complex signaling pathways, among which are the induction of defense proteins, release into the environment of volatile compounds that attract predators of herbivorous insects and the synthesis of secondary metabolites [21] [22].

In Table 2 it can be seen that there were significant differences for all parameters analyzed in relation to nutritional index: relative growth, relative consumption and efficiency of ingested food, in all varieties. Maize varieties differed significantly by Tukey test with the SP variety showing the highest consumption (0.87) and low efficiency in converting ingested food (7.72), suggesting insect resistance. Greater consumption is bad for the grain, for being the most attractive in the first $24 \mathrm{~h}$, it suffered greater damage. But this is bad for the insect too, since despite eating significantly more than of the other varieties, it has low growth $(0.06)$. The three studied characteristics are highly heritable and therefore show potential for success in selection with the use of the simplest methods of improvement [23].

S. zeamais had greater relative growth (Table 2) in purple corn (0.049), although not differing significantly from the ES variety (0.044). The population of $S$. zeamais had similar relative consumption when raised on the varieties purple straw SP and ES and differed significantly from purple corn, which had the lowest rate (0.50). The efficiency of conversion of ingested food was higher in purple corn (11.02), significantly differing from the varieties ES and SP. Comparing the values obtained for the number of emerged insects and consumption of grain by variety, it turns out that the ES variety gave the highest values for both parameters, characterizing it as the most susceptible to $S$. zeamais.

In relation to Table 3, no significant difference was observed among the landrace varieties for number of dead insects (NDI) or emergence of insects (EMERG), suggesting these materials are poorly suited to the development of $S$. zeamais. This suggests the existence of some factor of resistance probably not the type preferred for oviposition and/or feeding. The results obtained with respect to the number of emerged weevils are similar to those found by [24]. The authors found that in more resistant hybrids the number of emerged adults was less than 65 . They also showed that the coefficients of variation (CV\%) for emerged insects were similar to 
Table 1. Percentage attractiveness of $S$. zeamais to two varieties of maize (in new breeding program), in free choice test, after 72 hours of exposure (Bom Jesus, PI, 2012)

\begin{tabular}{|c|c|c|c|c|c|c|c|}
\hline \multicolumn{8}{|c|}{ Time } \\
\hline & & $0.5 \mathrm{~h}$ & $1 \mathrm{~h}$ & $12 \mathrm{~h}$ & $24 \mathrm{~h}$ & $48 \mathrm{~h}$ & $72 \mathrm{~h}$ \\
\hline SV & DF & & & MS & & & \\
\hline Genotypes & 4 & $34.34 \mathrm{~ns}$ & $91.66^{* *}$ & $166.36^{* *}$ & $107.46^{* *}$ & $25.26^{*}$ & $73.1^{*}$ \\
\hline Error & 20 & 15.94 & 7.14 & 9.04 & 5.08 & 7.08 & 18.18 \\
\hline $\mathbf{h}^{2}$ & & 0.68 & 0.92 & 0.94 & 0.95 & 0.78 & 0.80 \\
\hline CV\% & & 60.86 & 27.6 & 31.71 & 35.66 & 64.58 & 76.13 \\
\hline Mean & & 6.56 & 9.68 & 9.48 & 6.32 & 4.12 & 5.6 \\
\hline Genotypes & & & & Means & & & \\
\hline Purple & & $7.2 \mathrm{a}$ & $7.2 \mathrm{~b}$ & $8.2 \mathrm{~b}$ & $7.4 \mathrm{~b}$ & $2.8 \mathrm{ab}$ & 7.8ab \\
\hline ES & & $2.2 \mathrm{a}$ & $6.8 \mathrm{~b}$ & $7.6 \mathrm{~b}$ & $3.2 \mathrm{~b}$ & $6.8 \mathrm{a}$ & $4.0 \mathrm{ab}$ \\
\hline SP & & 7.6a & $7.4 \mathrm{~b}$ & $6.8 \mathrm{~b}$ & $14.0 \mathrm{a}$ & 5.0ab & 4.6ab \\
\hline
\end{tabular}

${ }^{* * *}$, ns = significant at $5 \%$ and $1 \%$ probability level and not significant, respectively, by $\mathrm{F}$ test. Means followed by the same letter in the column do not differ by Tukey test at $5 \%$ probability. SV (Source of Variation), DF (Degrees of Freedom), MS (Mean Square), CV (Coefficient of Variation), ${ }^{2}$ (heritability).

Table 2. Nutritional index of adult maize weevil S. zeamais: relative growth rate (RGR), relative consumption rate (RCR) and efficiency of conversion of ingested food (ECI) in grains of maize landraces (Bom Jesus, PI, 2012).

\begin{tabular}{ccccc}
\hline SV & DF & RGR & RCR & ECI \\
\hline Genotypes & 2 & & MS & $46.08^{*}$ \\
Error & 27 & $0.001^{* *}$ & $0.38^{* *}$ & 12.8 \\
$\mathbf{h}^{2}$ & & 0.0001 & 0.07 & 0.78 \\
$\mathbf{C V} \%$ & 0.9 & 0.84 & 41.7 \\
Mean & 20.5 & 36.34 & 8.57 \\
Genotypes & 0.053 & 0.72 & $11.02 \mathrm{a}$ \\
Purple & & Means & $6.98 \mathrm{~b}$ \\
ES & & $0.049 \mathrm{~b}$ & $0.50 \mathrm{~b}$ & $7.72 \mathrm{~b}$ \\
SP & $0.044 \mathrm{~b}$ & $0.80 \mathrm{a}$ & $0.87 \mathrm{a}$ & $0.06 \mathrm{a}$ \\
\hline
\end{tabular}

** $\mathrm{ns}=$ significant at $5 \%$ and $1 \%$ probability level and not significant respectively by $\mathrm{F}$ test. Means followed by the same letter in the column do not differ by Tukey test at 5\% probability. SV (Source of Variation), DF (Degrees of Freedom), MS (Mean Square), CV (Coefficient of Variation), $\mathrm{h}^{2}$ (heritability).

Table 3. Population growth of one population of S. zeamais: number of dead insects (NDI) and emergence (EMERG) (Bom Jesus, PI, 2012).

\begin{tabular}{cccc}
\hline SV & DF & NDI & MS \\
\hline Genotypes & 2 & $43.3 \mathrm{~ns}$ & $13.33 \mathrm{~ns}$ \\
Error & 27 & 18.86 & 18.67 \\
$\mathbf{h}^{2}$ & & 0.69 & 0.41 \\
CV\% & 36.19 & 25.98 \\
Mean & 12 & 16.63 \\
Genotypes & Means & $17.3^{\mathrm{a}}$ \\
Purple & $14.4 \mathrm{a}$ & $17.3^{\mathrm{a}}$ \\
ES & $10.9 \mathrm{a}$ & $15.3^{\mathrm{a}}$ \\
SP & $10.7 \mathrm{a}$ & \\
\hline
\end{tabular}

* ** $\mathrm{ns}=$ significant at $5 \%$ and $1 \%$ probability level and not significant respectively by $\mathrm{F}$ test. Means followed by the same letter in the column do not differ by Tukey test at 5\% probability. SV (Source of Variation), DF (Degrees of Freedom), MS (Mean Square), CV (Coefficient of Variation), $\mathrm{h}^{2}$ (heritability). 
those found by [25] (26.66\%), working with resistant varieties of corn and entomopathogenic fungi for the control of S. zeamais.

According to [26], the smallest number of emerged insects in a given range is associated with some degree of resistance. The EMERG characteristic, of medium heritability, seems to be strongly influenced by the environment; factors such as humidity and temperature may have influenced this result, because stored grain pests derive the necessary moisture from foods to meet their vital processes; therefore, the level of relative humidity and grain moisture become critical factors for survival [11].

Similar results were also found by [18], where working with maize materials resistant to S. zeamais attack, found a low number of emerged insects (mean change between 12 and 15 insects). According to these authors, this fact may be associated with antibiosis, because as in the previous experiment (preference), the SP range is considered the most preferred in one of the evaluated times and some factor linked to the characteristics of the grain may have affected the development of the insects. Characteristics such as total protein and cellulose may be related to this momentary preference. Further testing was not performed in this study.

\section{Conclusion}

Considering all parameters, maize cultivars differ in food preference and resistance to $S$. zeamais, with cultivar SP considered the most resistant among the materials tested.

\section{References}

[1] Guimarães, J.L. (2010) Preparation and Characterization of Composite Plasticized Starch with Glycerol and Vegetable Reinforced with Natural Fibers. Doctoral Thesis, Federal University of Paraná, Curitiba.

[2] Duete, R.R.C., Muraoka, T., Silva, E.C.S., Trivelin, P.C.O. and Ambrosano, E.J. (2009) Economic Viability of Doses and Split-Applications of Nitrogen Fertilization in Corn Crop in a Eutrophic Red Latosol. Acta Scientiarum Agronomy, 31, 175-181.

[3] Souza, P.M. and Braga, M.J. (2004) Economics Aspects of Production and Marketing of Maize in Brazil. In: Galvão, J.C.C. and Miranda, G.V., Eds., Technology of Production of Corn, UFV, Viçosa, 13-53.

[4] Garbuglio, D.D., De Miranda Filho, J.B. and Cella, M. (2009) Genetic Variability in S1 Families from Different Maize Populations. Acta Scientiarum Agronomy, 31, 209-213.

[5] Bueno, L.C. de S., Mendes, A.N.G. and Carvalho, S.P. (2006) Plant Breeding: Principles and Procedures. 2nd Edition, UFLA, Lavras, 319.

[6] Silva, W., Paterniani, E., Sologuren, L. and Di Ciero, L. (2006) Corn Guide: Technology from Field to Table. Council for Biotechnology Information (CIB).

https://www.google.com.br/?gfe_rd=cr\&ei=loA0U7HND4uk8wfX9oHQBA\#q=guia+do+milho+cib

[7] Cardoso, M.J., De Carvalho, H.W.L., Leal, M.L.S. and Dos Santos, M.X. (2003) Genetic Improvement of Corn Cultivars CMS 47 and BR 5039 (São Vicente) in Mid-Northern Brazil. Brazilian Journal of Maize and Sorghum, 2, 88-96.

[8] Silveira, R.D., Faroni, L.R.D., Pimentel, M.A.G. and Zocolo, G.J. (2006) Effect of Maize Grain Temperature at Spraying, and of Storage Duration, on Mortality of Sitophilus zeamais and Tribolium castneum, Using a Mixture of Bifenthrin and Pirimiphos-Methyl. Brazilian Magazine Storage, 31, 120-124.

[9] Mazzonetto, F. and Vendramim, J.D. (2002) Biological Aspects of Zabrotes subfasciatus (Boh.) (Coleoptera: Bruchidae) on Bean Genotypes with and without Arcelin. Neotropical Entomology, 31, 435-439. http://dx.doi.org/10.1590/S1519-566X2002000300013

[10] Potrich, M., Alves, L.F.A., Mertz, N.R., Bonini, A.K., Da Silva, E.R.L. and Marchese, L.P.C. (2010) Selection and Association of Resistent Varieties of Corn with Beauveria bassiana for Control of Sitophilus zeamais (Coleoptera: Curculionidae). Semina: Agricultural Sciences, 31, 5-18.

[11] Morais, A.A. and Pinheiro, J.B. (2012) Breeding for Resistance to Insect Pests. In: Fritsche-Neto, R. and Borém, A., Eds., Plant Breeding for Biotic Stress Conditions, Suprema, Viçosa, MG, 153-185.

[12] Singh, S.R. and McCain, F.S. (1963) Relationship of Some Nutritional Properties of the Corn Kernel to Weevil Infestation. Crop Science, 3, 259-261. http://dx.doi.org/10.2135/cropsci1963.0011183X000300030027x

[13] Veiga, A.F.S.L. (1969) Relative Susceptibility of Different Races of Maize from Latin America, Hybrids and Commercial Varieties in Brazil to Weevil (Sitophilus zeamais Motschulsky 1855) and Moth (Sitotroga cerealella Olivier), a Pest of Stored Grain, in Laboratory Conditions. Master Dissertation, Esalq-USP, Piracicaba, SP.

[14] Da Cunha, F.L. (2013) Seeds of Passion and Public Policies Seed Distribution in Paraíba. Master Dissertation, Federal Rural University of Rio de Janeiro, Institute of Forestry, Seropédica. 
[15] Isman, M.B., Koul, O., Luczynski, A. and Kaminski, J. (1990) Insectisidal and Antifeedant Bioactivities of Nem Oils and Their Relationship to Azadiractin Content. Journal of Agricultural and Food Chemistry, 38, 1406-1411. http://dx.doi.org/10.1021/jf00096a024

[16] Huang, Y., Tan, J.M.W.L., Kini, R.M. and Ho, S.H. (1997) Toxic and Antifeedant Action of Nutmeg Oil against Tribolium castaneum (Herbst) and Sitophilus zeamais Motsch. Journal of Stored Products Research, 33, 289-298. http://dx.doi.org/10.1016/S0022-474X(97)00009-X

[17] Vencovsky, R. and Barriga, P. (1992) Biometric Genetics in Plant Breeding. Brazilian Society of Genetics, Ribeirão Preto, 496.

[18] Santos, J.P. and Foster, J.E. (1981) Identification of Maize Kernels Resistant to the Maize Weevils. Brazilian Agricultural Research, 16, 39-43.

[19] Guedes, N.M.P. (2008) Behavior in Populations of Sitophilus Zeamais Resistant to Insecticides. Doctoral Thesis, Federal University of Viçosa, Minas Gerais.

[20] Guzzo, E.C., Alves, L.F.A., Zanin, A. and Vendramin, J.D. (2002) Identification of Resistant Maize to Maize Weevil Sitophilus zeamais (Mots., 1855) (Coleoptera: Curculionidae). Arquivos do Instituto Biológico, 69, 69-73.

[21] Falco, M.C., Marbach, P.A.S., Pompermayer, P., Lopes, F.C.C. and Silva-Filho, M.C. (2001) Mechanisms of Sugarcane Response to Herbivory. Genetics and Molecular Biology, 24, 113-122. http://dx.doi.org/10.1590/S1415-47572001000100016

[22] Mello, M.O. and Silva-Filho, M.C. (2002) Plant-Insect Interactions: An Evolutionary Arms Race between Two Distinct Defense Mechanisms. Brazilian Journal of Plant Physiology, 14, 71-81. http://dx.doi.org/10.1590/S1677-04202002000200001

[23] Cruz, C.D. (2005) Principles of Quantitative Genetics. UFV, Viçosa, 394 p.

[24] Marsaro Júnior, A.L., Lazzari, S.M.N., Figueira, E.L.Z. and Hirooka, E.Y. (2005) Amylase Inhibitors in Corn Hybrids as a Resistance Factor to Sitophilus zeamais (Coleoptera: Curculionidae). Neotropical Entomology, 34, 443-450. http://dx.doi.org/10.1590/S1519-566X2005000300013

[25] Potrich, M. (2006) Association Resistant Maize Varieties and Entomopathogenic Fungi for Control of Sitophilus spp. Master Dissertation, State University of West Paraná, Marechal Cândido Rondon.

[26] Lara, F.M. (1991) Principles of Plant Resistance to Insects. 2nd Edition, Ícone, São Paulo, 336. 
Scientific Research Publishing (SCIRP) is one of the largest Open Access journal publishers. It is currently publishing more than 200 open access, online, peer-reviewed journals covering a wide range of academic disciplines. SCIRP serves the worldwide academic communities and contributes to the progress and application of science with its publication.

Other selected journals from SCIRP are listed as below. Submit your manuscript to us via either submit@scirp.org or Online Submission Portal.
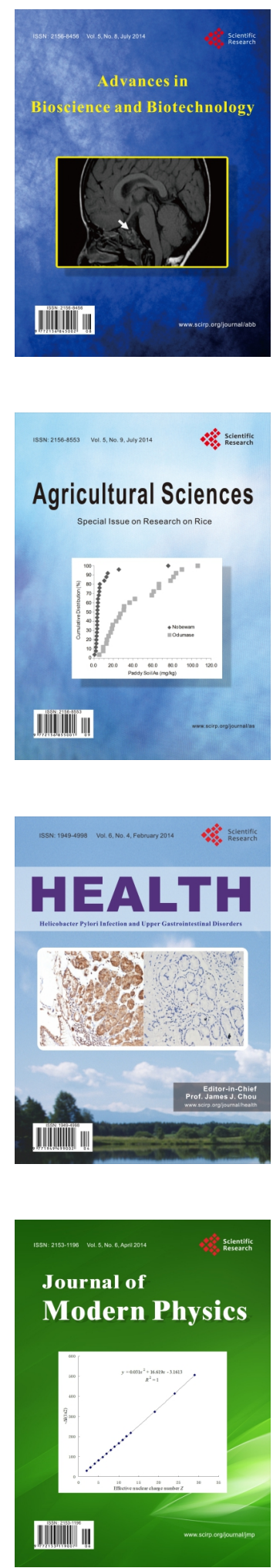
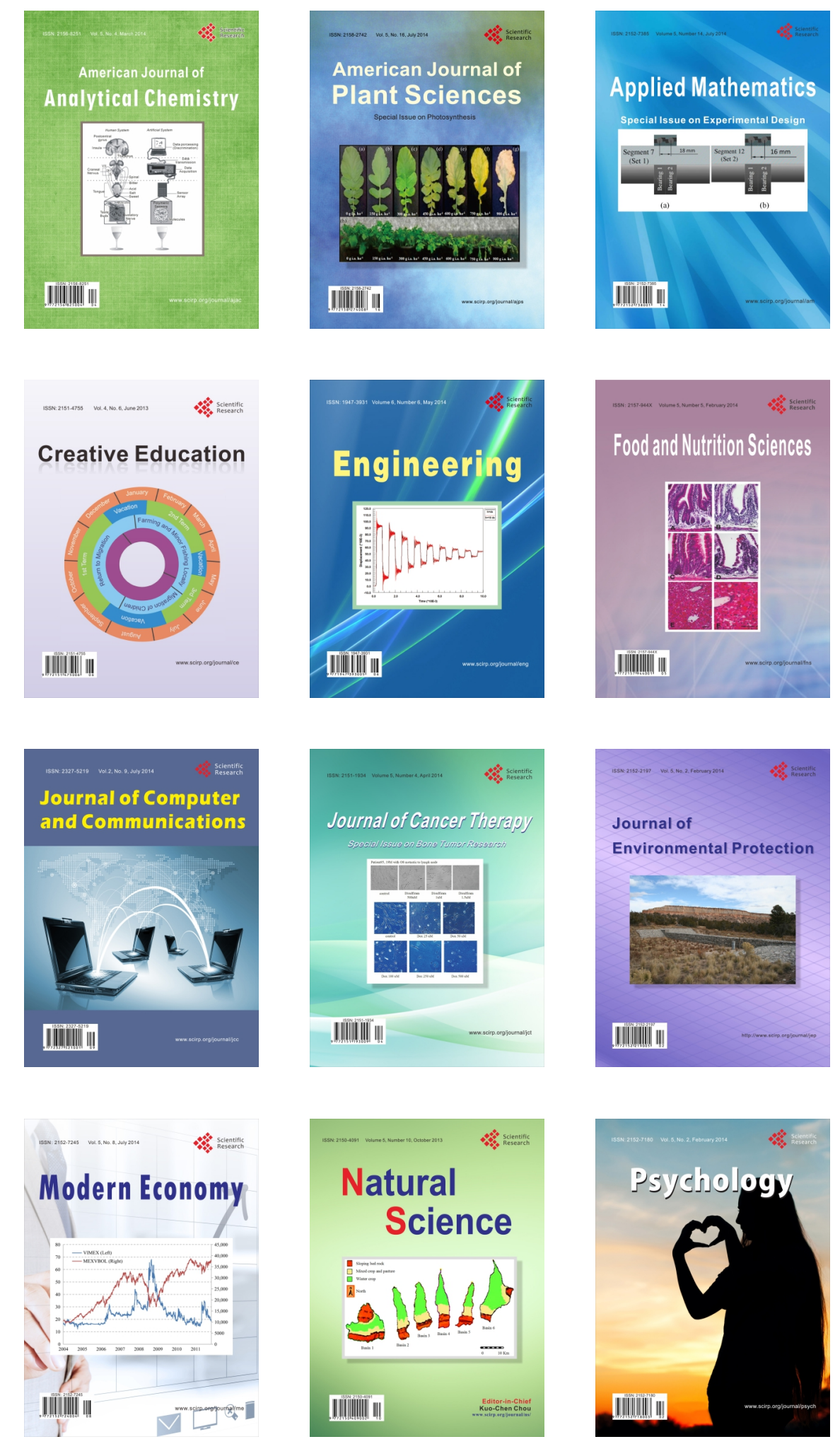